\title{
Preservation of bone flap after craniotomy infection
}

\author{
P.D. Delgado-López; V. Martín-Velasco; J.M. Castilla-Díez; A.M. Galacho-Harriero y A. Rodríguez-Salazar
}

Servicio de Neurocirugía. Hospital General Yagüe, Burgos.

\section{Summary}

Introduction. The estimated incidence of craniotomy infection is $5 \%$, ranging from $1-11 \%$ depending on the presence of certain risk factors, such as, prior radiation therapy, repeated surgery, CSF leak, duration of surgery over $4 \mathrm{~h}$, interventions involving nasal sinuses and emergency surgeries. The standard treatment for infected craniotomies is bone flap discarding and delayed cranioplasty. Adequate cosmetic results, unprotected brain and disfiguring deformity until cranioplasty are controversial features following bone removal. We present a limited series of five patients with craniotomy infection, that were successfully treated with wound debridement, in situ bone sterilization, reposition of the bone flap and antibiotic irrigation through a wash-in and wash-out draining system, all in the same surgical procedure. All infections cleared and every patient saved his/her bone flap.

Patients and methods. We retrospectively reviewed the records of 5 patients with craniotomy infection that presented with wound swelling, purulent discharge and fever. The operative technique consisted on three manoeuvres: wound debridement, bone flap sterilization (either autoclaved or soaked in a sterilizing solution), and insertion of subgaleal/epidural drains for non-continuous antibiotic irrigation (vancomycin 50mg in $20 \mathrm{cc}$ of saline every $12 \mathrm{~h}$ alternating with cephotaxime $100 \mathrm{mg}$ in $20 \mathrm{cc}$ of saline every $12 \mathrm{~h}$ ). Also, patients received equal systemic endovenous antibiotherapy and oral antibiotics after discharge, until complete resolution of infection and wound healing.

Results. Patients in the series ( 2 women and 3 men) ranged in age from 36 to 77 . No patient had received prior radiation therapy and only one had undergone surgery involving nasal sinuses. The initial operations correspond to craniotomies performed for two intracranial tumours (meningiomas), one arteriovenous malformation and two decompressive craniotomies

Recibido: 14-11-07. Aceptado: 16-01-08 (haemorrhagic contusions and acute subdural haematoma). The duration of surgeries ranged from $1 \mathrm{~h} 30$ ' to 5h30', only two operations extending over 4 hours. The interval between the initial surgery and the reintervention ranged from 11 to 227 days. Staphyloccocus spp were cultured in all patients. For bone sterilization povidone scrubbing was used in all patients, autoclave in two and soaking the flap in a sterilizing solution in three. All patients cleared infection and achieved complete wound healing in 2-3 weeks after the re-operation. Follow up ranged from 4 to 18 months. One patient died as a consequence of sepsis in the context of pneumonia some weeks after wound healing.

Discussion. Recent multivariate analyses have demonstrated that the presence of a CSF leak and the performance of repeated operations are the most important independent risk factors for craniotomy infection, with associated odds ratios for infection as high as 145 and 7, respectively. Regular antibiotic administration at anaesthesia induction seems to decrease the rate of craniotomy infection by half, both in the entire population and in low-risk subsets. Organisms involved in craniotomy infections are common pathogens usually contaminating neurosurgical procedures or normal skin flora germs. Auguste and McDermott have recently presented a case series of 12 patients in which successful salvage procedures for infected craniotomy bone flaps were performed using a continuous wash-in, wash-out indwelling antibiotic irrigation system, that needed close observation of the neurological status since obstruction of the outflow system could precipitate brain herniation. The method we present is as effective as theirs and avoids such complication since only small quantities of antibiotic solutions (20 cc) are instilled during each dose administration.

KEY WORDS: Infection. Bone flap. Osteomyelitis.

Preservación del colgajo óseo en infección de craneotomía 


\section{Resumen}

Introducción. La incidencia de infecciones de craneotomía está en torno al $5 \%$, con un rango entre $\mathbf{1 - 1 1 \%}$ dependiendo de la presencia de ciertos factores de riesgo como son la radioterapia previa, fístula de LCR, cirugías urgentes, repetidas o que afectan a senos paranasales o una duración mayor de 4 h. Tradicionalmente, los colgajos óseos infectados se han reintervenido mediante retirada y abandono del hueso y craneoplastia diferida. Esta situación desprotege temporalmente el cerebro, desfigura la calota y no siempre se obtienen resultados cosméticos óptimos tras la reconstrucción. Presentamos una serie de 5 pacientes con infección del colgajo óseo en los que, en un mismo acto quirúrgico, se realizó desbridamiento quirúrgico, esterilización del colgajo y colocación de drenajes para lavados intermitentes con antibióticos, de manera que todos los huesos pudieron salvarse.

Pacientes y métodos. Estudio retrospectivo sobre 5 pacientes con infección de colgajo óseo de craneotomía. La técnica quirúrgica empleada en las reintervenciones constaba de tres pasos: desbridamiento y limpieza de la herida purulenta, esterilización ósea (mediante autoclave o inmersión en solución esterilizante), e inserción de drenajes subgaleales/epidurales para lavado con antibióticos (vancomicina $50 \mathrm{mg}$ en $20 \mathrm{cc}$ SF /12h alternando con cefotaxima $100 \mathrm{~m}$ en $20 \mathrm{cc} \mathrm{SF} / 12 \mathrm{~h})$. Todos recibieron la misma antibioterapia sistémica intravenosa y antibióticos orales tras el alta, hasta la completa curación de la herida.

Resultados. Las edades de los pacientes ( 2 mujeres y 3 varones) estuvieron comprendidas entre 36 y 77 años. Ningún paciente había recibido radioterapia previa y sólo en un paciente la intervención afectó un seno paranasal. Las intervenciones iniciales se realizaron para dos tumores intracraneales (meningiomas), una MAV y dos craniectomías descompresivas. La duración de las intervenciones estuvo entre 1h30' y 5h30'; sólo en dos ocasiones más de $4 \mathrm{~h}$. El intervalo hasta la reintervención estuvo entre 11 y 227 días. Se cultivaron diversas especies de Staphyloccocus en todos los pacientes. La esterilización se realizó mediante cepillado con povidona yodada y autoclave ( 2 pacientes) o solución esterilizante (3). Todas las infecciones se resolvieron en 2-3 semanas tras la reoperación. El seguimiento estuvo entre 4 y 18 meses. Una paciente murió por sepsis varias semanas tras la curación del colgajo.

Discusión. Estudios multivariantes han demostrado que la presencia de fístula de LCR y las reintervenciones son los factores de riesgo independientes más importantes para infección del colgajo óseo, con odds ratio asociadas de 145 y 7 , respectivamente. La administra- ción regular de antibióticos profilácticos durante la inducción anestésica parece disminuir a la mitad la tasa de infecciones en todos los subgrupos de pacientes. Los gérmenes aislados suelen ser contaminantes propios de los procedimientos neuroquirúrgicos y/o flora cutánea. Auguste y McDermott han presentado recientemente una serie de 12 pacientes con infección del colgajo óseo en los que pudieron salvar el hueso con un sistema de lavado con antibióticos a través de drenajes, en el que era imprescindible la vigilancia neurológica estrecha por el teórico riesgo de obstrucción del sistema de lavado continuo y posible herniación cerebral. El sistema que presentamos resulta igual de efectivo y evita dicha complicación pues la cantidad de volumen con antibiótico que se administra en cada dosis no supera los 20cc.

PALABRAS CLAVE: Infección. Colgajo óseo. Osteomielitis

\section{Introduction}

Infection is a relatively uncommon complication of craniotomy. The estimated incidence is less than $5 \%$ of all craniotomy approaches, ranging from 1-11\%, depending on whether certain risk factors are present ${ }^{2,3,13,14,22}$. Previously reported predisposing factors for craniotomy infection are prior radiation therapy, repeated surgery, CSF leak, duration of surgery over four hours, interventions involving nasal sinuses and emergency surgeries ${ }^{2,3,5,13,14}$. The term "craniotomy infection" does not necessarily imply the presence of purulent collections in a cranial space in particular (either subgaleal, epidural or below the dura mater). It is usually referred to as a clinical setting consisting on wound swelling and erythema, purulent discharge through the skin, at least partial wound dehiscence, and general signs of infection like fever, anorexia or malaise ${ }^{13}$.

Traditionally, infected bone flaps have been surgically removed and discarded ${ }^{1,2,5,11}$. This standardized management implies the performance of a delayed cranioplasty once the infection is cleared. Although this is a safe procedure and several simple-to-use cranioplasty materials have been developed, excellent cosmetic results are not always easy to achieve. Besides, there is a time interval in which the underlying brain is exposed to injury and the patient exhibits a somehow disfiguring deformity.

Attempts to salvage infected craniotomies as an alternative to bone flap removal have been reported in the literature. Simple debridement, suction-irrigation systems or wash-in, wash-out indwelling antibiotic irrigation methods have been used with favourable results ${ }^{1,5}$. We present a limited series of five patients with the diagnosis of craniotomy infection, that were successfully treated with wound 


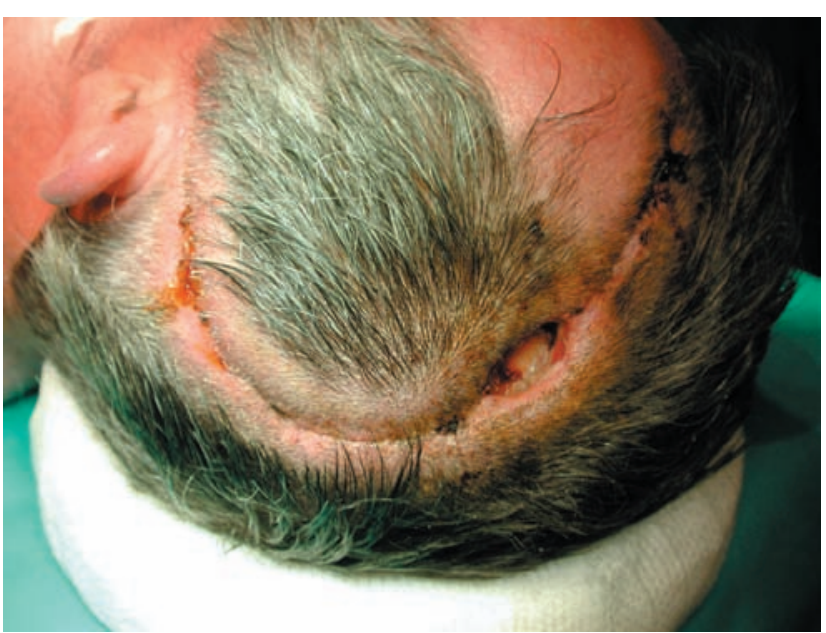

Figure 1. Wound dehiscence with purulent material discharge in the upper part of the incision (case number 5).

debridement, intraoperative bone sterilization, reposition of the bone flap and antibiotic irrigation through wash-in and wash-out drains in the same surgical procedure. All infections resolved and every patient saved his/her bone flap. Some technical aspects of this procedure are also discussed.

\section{Patients and methods}

We retrospectively reviewed the records of 5 patients in whom a craniotomy infection was diagnosed. All presented with wound swelling and dehiscence, purulent discharge and fever (Figure 1). Four neurosurgeons participated in the surgeries. The technique consisted on three consecutive manoeuvres (Figure 2). First, the wound was reopened, all devitalized tissues were carefully removed, purulent collections were thoroughly cleaned and samples for microbiological culture obtained. Second, the bone flap was removed, scrubbed on both sides and sent for sterilization (either autoclaved at $130^{\circ} \mathrm{C}$ and atmosphere pressure during 20 minutes, or soaked in a sterilizing solution like povidone iodine or clohexidine for 30 minutes) before replacement. Hemostasis was achieved with bipolar forceps and the aid of absorbable hemostatic agents. Duraplasty was performed when needed (Duraform ${ }^{\circledR}$, Johnson\&Johnson). New bone fixation material was used to secure the flap to the skull. Third, two drains were placed in the subgaleal and/or epidural spaces: a ventricular drain catheter (Bactiseal ${ }^{\circledR}$, Johnson\&Johnson) for antibiotic instillation and a wider drain for evacuation. The wound was closed in a single layer with non-absorbable suture. The drains were tunnelled away the incision line and secured with suture. The patient is allowed to ambulate the next day.

Antibiotic solution through the ventricular catheter was administered every 6 hours, kept inside the wound for one hour (no more than $20 \mathrm{cc}$ each time) with the wash-out drainage tube closed during that interval and then opened to evacuate the solution and debris until the next administration. Doses for antibiotic irrigation were as follows: vancomycin $50 \mathrm{mg}$ in $20 \mathrm{cc}$ of saline every $12 \mathrm{~h}$ alternating with cephotaxime $100 \mathrm{mg}$ in $20 \mathrm{cc}$ of saline every $12 \mathrm{~h}$. Drains were kept in place for several days depending on the process of wound healing. Systemic intravenous antibiotic therapy was administered to all patients as well during 14 days. Doses of systemic endovenous vancomycin and cephotaxime were $1 \mathrm{~g} / 12 \mathrm{~h}$ and $2 \mathrm{~g} / 8 \mathrm{~h}$, respectively. After discharge, patients were placed on oral antibiotics for several weeks and followed in the outpatient office until resolution of the infection and complete wound healing (see Table 1 for details).

\section{Results}

Patients in the series ( 2 women and 3 men) ranged in age from 36 to 77 . Table 1 summarizes the clinical data of the patients. Infections occurred in the time period from May 2005 to October 2006. The total number of craniotomies performed in that period was 209 and the overall rate of infection was $2.4 \%$. No patient had received prior radiation therapy and only one (case number 2) had undergone an operation involving nasal sinuses (frontal sinus). The initial interventions correspond to craniotomies performed for two intracranial tumours (meningiomas), one arteriovenous malformation and two decompressive craniectomies (for haemorrhagic contusions and acute subdural haematoma, respectively). The duration of surgeries ranged from $1 \mathrm{~h} 30$ ' to 5 h30', only two interventions extending over 4 hours. The time interval between the initial surgery and the intervention for the infected craniotomy ranged from 11 to 227 days. All patients presented with wound dehiscence, abundant purulent discharge and fever. Radiologic examination of the flap showed no evident signs of bone resorption; only mild marginal osteolysis in one patient (case number 1, Figure 2).

Organisms cultured in wound samples are listed in Table 1. Staphyloccocus spp were cultured in all patients. For bone sterilization povidone scrubbing was used in all patients, autoclave in two and soaking the flap in a sterilizing solution in three. Wound debridement and drain placement was a standardized feature in all re-operations, as well as antibiotic irrigation and systemic dosage as described above. Outpatient medication varied according to drug tolerance and organism sensitivity as it is referred in Table 1. All patients cleared infection and achieved complete wound healing in 2-3 weeks after the re-operation. Follow up ranged from 4 to 18 months. One patient (case number 2) died as a consequence of sepsis in the context of pneumonia five weeks after wound healing. Another patient 


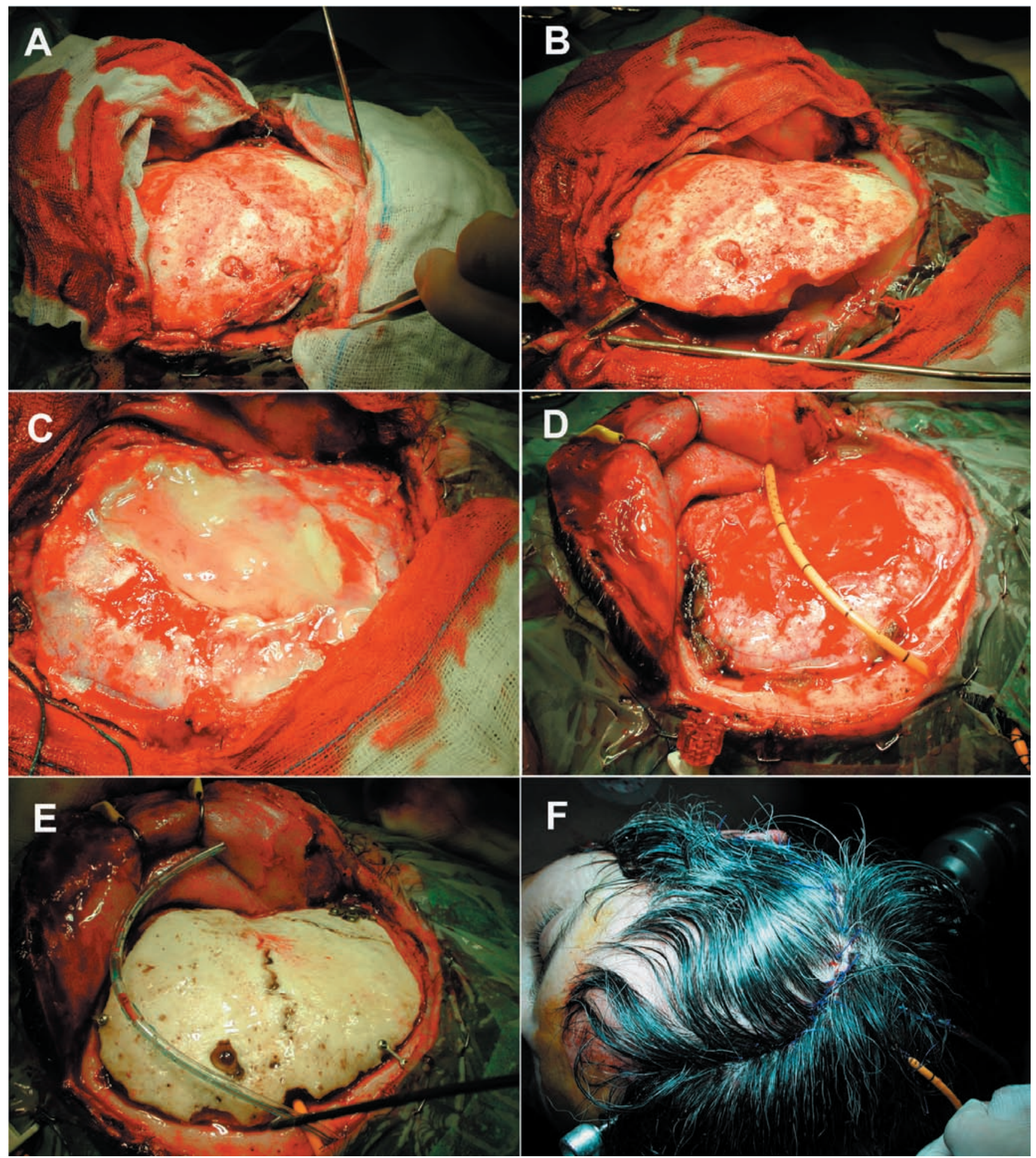

Figure 2. A: the wound is reopened (images correspond to case number 1). B: when the bone flap is elevated, an abundant purulent collection is observed as it flows outward. C: yellowish pus is adherent to a Gore-Tex dural plastia implanted in the previous operation. D: after cleaning the purulent material, an antibiotic-impregnated external ventricular drain is inserted epidurally for antibiotic irrigation. E: the bone is sent for autoclave sterilizing (note the pale colour of the bone after the procedure) and the replaced with new skull fixation material. A second drain is inserted on the subgaleal space for antibiotic and debris evacuation. F: the scalp is closed with a single-layer suture. Drains are properly secured with non-absorbable suture. 


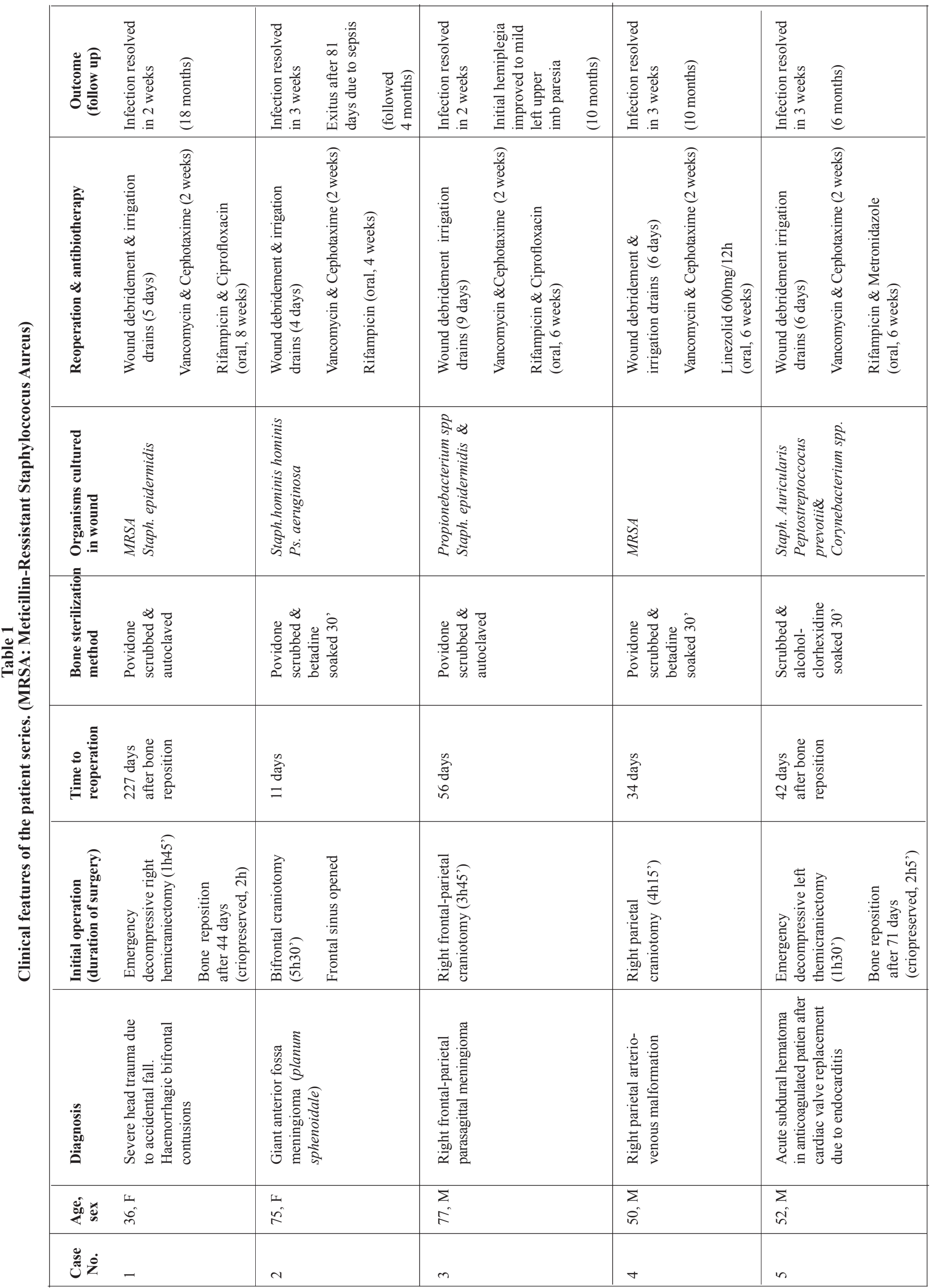


suffered left hemiparesis after the initial intervention that resulted in hemiplegia when the infection occurred but ultimately improved to mild left upper limb paresis after ten months follow up.

\section{Discussion}

Bone flap infection after craniotomy is a burdensome but fortunately uncommon complication following neurosurgical procedures. Overall infection rate in large craniotomy series ranges from $4 \%$ to $6.6 \%$, including patients harbouring simple superficial wound infections, bone flap osteitis, meningitis or brain abscesses ${ }^{13,14}$. This range may be wider depending on the presence or not of certain risk factors. Malis reported a zero rate of infection over 1732 interventions in a commonly quoted paper from Neurosurgery in 1979, where he recommended intraoperative antibiotics ${ }^{17}$. Only, about half of all postneurosurgical infections correspond to true bone flap infections ${ }^{3}$. Postcraniotomy meningitis seems to be increased in patients undergoing interventions entering the sinus, those harbouring external ventricular drains or intracranial pressure probes and patients with higher ASA score, as it has been recently reported ${ }^{15}$.

The distinction between superficial cranial wound infection and deep wound infection seems only theoretical since the subgaleal and epidural compartments are in contiguity when a craniotomy is performed. In our view, any craniotomy infection can be considered a bone flap osteitis as far as the treatment is concerned. Also, some degree of bone resorption can be ascertained in the x-ray films or CT scans in many cases, depending on the latency until the infection is diagnosed. The standard management of bone flap osteitis includes wound debridement, bone removal and discarding and delayed cranioplasty with acrylic material or other substitute ${ }^{1,2,5,11}$.

Risk factors for craniotomy infection have been identified in several studies. Multivariate analyses have demonstrated that the presence of a CSF leak and the performance of repeated operations are the main independent risk factors for craniotomy infection, with associated odds ratios for infection as high as 145 and 7 , respectively ${ }^{13,14}$. Other predictive risk factors include: prior radiation therapy, surgical duration of more than 4 hours, early re-operation or emergency operation and the performance of skull base procedures, especially those involving nasal sinuses ${ }^{5,14}$. The absence of antibiotic prophylaxis also seems to predispose to infection ${ }^{2,14}$. The patient's age, the individual surgeon or the number of operations per surgeon are still uncertain and debatable risk factors ${ }^{3,14}$. No reliable data is available on the influence of other possible factors such as prior comorbidity, medications used in common neuro-anaesthetic procedures, the type of incision (lineal versus curved flaps) or whether the scalp was shaved or not. Castilla et al have reported that minimum shaving of the incision line scalp does not seem to predispose to infection ${ }^{6}$. A retrospective study over 202 craniotomies performed to evaluate the incidence of infection in osteoplastic bone flaps (75 patients) versus free bone flaps (127 patients) showed that the removal of the bone was necessary to accomplish healing in 1/5 infected osteoplastic but in $4 / 8$ infected free bone flaps, suggesting that osteoplastic bone flaps can be more often preserved in cases of craniotomy infection ${ }^{22}$.

The rationale for the use of antibiotic prophylaxis relies on the fact that free craniotomy flaps are devascularized bones with a reduced resistance to infection and, once contaminated, this osteitis requires surgical removal. Regular antibiotic administration at anaesthesia induction seems to decrease the rate of craniotomy infection in about $50 \%$, both in the entire population and in low-risk subsets, as it has been demonstrated in several clinical trials ${ }^{4,7,14,18,21}$. Administration of a single prophylactic dose of vancomycin was recommended in a large randomized trial on the basis of a significantly reduced bone flap infection rate ${ }^{4}$. Other trials have shown that second and third generation cephalosporin ${ }^{7,21}$ or fusidic acid ${ }^{18}$ seem to be as effective as vancomycin or combined treatments for preventing craniotomy infection.

Various methods of bone flap sterilization are available. Commonly, they may be autoclaved or soaked in sterilizing solutions. Parameters for autoclave procedure or which type of solution (hydrogen peroxide, povidone-iodine, clorhexidine or others) is optimum are not well-defined features. Infiltrated bone flaps by tumoural cells have been successfully re-implanted after being autoclaved for 20 minutes at $134^{\circ} \mathrm{C}$ and one atmosphere pressure ${ }^{23}$. No data is available in the literature concerning the best parameters in case of infected flaps. In any case, bone sterilization can be easily performed intraoperatively. Some authors consider indispensable autoclave sterilization of a frozen-preserved bone flap before reposition, a method that does not seem to increase the risk of infection or bone resorption ${ }^{20}$.

A recent paper on the incidence and outcome of intraoperatively contaminated bone flaps due to accidental dropping to the floor during craniotomy showed that, in the author's experience, infections can be avoided by autoclaving or soaking the flap in betadine and/or antibiotic solution; only a minority of patients needed discarding of the bone and cranioplasty ${ }^{10}$. Although not a sterilizing method, hyperbaric oxygen treatment has been evaluated as a therapeutic method for infections after craniotomy or laminectomy. In both uncomplicated and complicated (radiation injury, malignancy, repeated surgery or implants) cranial wound infections, bone flaps could be retained in the great majority of cases after hyperbaric treatment. Also, all spinal cases undergoing hyperbaric therapy resolved 
without the removal of fixation systems ${ }^{16}$.

Organisms involved in craniotomy infections are common pathogens usually contaminating neurosurgical procedures or normal skin flora germs. These include gram-positive cocci (such as Staphylococcus aureus or $\mathrm{S}$. epidermidis), gram-negative bacilli and other less common organisms ${ }^{1,222}$. Propionibacterium acnes is commonly isolated but usually considered a contaminant. In the context of neurosurgical procedures it can cause postoperative CSF or craniotomy flap infections ${ }^{9,11}$. They are usually cultured in slow infections presenting months or even years postoperatively. Adequate antibiotic coverage and wound debridement with or without flap removal results in cure of most of the patients ${ }^{11}$. In all patients in the present series species of Staphyloccocus were cultured, two cases demonstrating strains of $S$. aureus resistant to meticillin, successfully managed with vancomycin.

Sterile preservation of a surgically removed bone flap until reposition is mandatory. Options include frozen ${ }^{8,20}$, subcutaneous $^{19}$ and under-the-scalp ${ }^{12}$ preservation. Clinical and cosmetic results of delayed cranioplasty using frozen autogenous bone flaps have been satisfactory with a reported $2 \%$ rate of infection ${ }^{8}$. Likewise, subcutaneous storage of bone flaps placed in the abdominal wall allows delayed cranioplasty with a low revision rate ${ }^{19}$. Still, in these preserved bones there is a chance for non-sterile conservation due to technical reasons or contamination during the intraoperative handling. That is why sterilizing the bone immediately before replacing it may be a recommended manoeuvre. We performed two emergency decompressive hemicraniectomies that needed bone reposition after 44 and 71 days. Bones were kept in a $-60^{\circ} \mathrm{C}$ fridge inside double sterile bags. None of them were sterilized at the time of reposition. One of the bones was autoclaved (Figure 2) and the other soaked in a sterilizing solution at the moment of the third surgery.

Auguste and McDermott have recently published in Journal of Neurosurgery a case series of 12 patients in which salvage procedures for infected craniotomy bone flaps were performed ${ }^{1}$. They used a continuous wash-in, wash-out indwelling antibiotic irrigation system through two subgaleal and epidural drains. They were able to clear the infection and save all but one bone flap. The authors recommended close observation of the neurological status (every 1-2 hours) in all patients undergoing continuous antibiotic irrigation since obstruction of the outflow system can precipitate excessive accumulation of fluid inside the skull and produce brain compression. We believe that such a neurological deterioration can be avoided if only small quantities of antibiotic solution are utilized, thus being unnecessary such a close neurological watch. As in the cases described above, no neurological deterioration is expected if only $20 \mathrm{cc}$ of fluid is instilled under the flap each time and then let go. These authors also advocate for the use of both epidural and subgaleal inflow and outflow drains for proper antibiotic irrigation. From a theoretical point of view, the gap between the free bone flap and the skull edge allows direct communication between the subgaleal and epidural space (even to the subdural space, because watertight dural sealing is sometimes difficult despite the use of modern sealants). When the antibiotic solution is instilled and kept inside for a period of time of, at least, some minutes, it is reasonable to believe that subgaleal and epidural spaces are bathed in the same antimicrobial fluid, making the insertion of epidural drains, probably, unnecessary. Still, sound evidence on the efficacy of topic or locally administered antibiotics is lacking. We used subgaleal drains in all cases but epidural drains in only one (case number 1, Figure 2). Antibiotic-impregnated ventricular drains used for inflow irrigation may be of help in craniotomy infections due to its capability to elute antibiotics inside the wound and diminish the chance of contamination attributable to the insertion of the drain itself.

Even though this is a very limited series of patients, we were able to clear all the craniotomy infections and save every bone. Complete wound healing was achieved in all patients and no further interventions were needed. It is our aim to stress the fact that maintaining a patient several weeks or months waiting for a cranioplasty is a rather disturbing situation that exposes the brain to injury and creates a remarkable disfiguration. Realising that this is a small case series and the follow up period is still short to conclude on the efficacy of the procedure, it is our view that wound debridement, intraoperative bone sterilization and reposition, and non-continuous antibiotic irrigation is a feasible intervention that should be considered a reasonable alternative to bone removal and delayed cranioplasty for infected craniotomies.

\section{References}

1. Auguste, K.I., McDermott, M.W.: Salvage of infected craniotomy bone flaps with the wash-in, wash-out indwelling antibiotic irrigation system. Technical note and case series of 12 patients. J Neurosurg 2006; 105: 640-644.

2. Blomstedt, G.C.: Craniotomy infections. Neurosurg Clin N Am 1992; 3: 375-385.

3. Blomstedt, G.C.: Infections in neurosurgery: a retrospective study of 1143 patients and 1517 operations. Acta Neurochir (Wien) 1985; 78: 81-90.

4. Blomstedt, G.C., Kytta, J.: Results of a randomized trial of vancomycin prophylaxis in craniotomy. J Neurosurg 1988; 69: 216-220.

5. Bruce, J.N., Bruce, S.S.: Preservation of bone flaps in patients with postcraniotomy infections. J Neurosurg 2003; 98: 1203-1207. 
6. Castilla, J.M., Borrás, J.M., Gómez-Sierra, A., Rodríguez de Lope, A., Núñez, M., Carrillo, R.: Rasurado mínimo en neurocirugía. Neurocirugía 1995; 6: 288-294.

7. Gaillard, T., Gilsbach, J.M.: Intra-operative antibiotic prophylaxis in neurosurgery. A prospective, randomized, controlled study on cefotiam. Acta Neurochir (Wien) 1991; 113: 103-109.

8. Iwama, T., Yamada, J., Imai, S., Shinoda, J., Funakoshi, T., Sakai, N.: The use of frozen autogenous bone flaps in delayed cranioplasty revisited. Neurosurgery 2003; 52: 591-596.

9. Jallo, G.I., Koslow, M., Hana, B.A., Carson, L.A.: Propionibacterium as a cause of postneurosurgical infection inpatients with dural allografts: report of three cases. Neurosurgery 1999; 44: 1138-1141.

10. Jankowitz, B.T., Kondziolka, D.S.: When the bone flap hits the floor. Neurosurgery 2006; 59: 585-590.

11. Kelly, M.E., Fourney, D.R., Guzman, R., Sadanand, V., Griebel, R.W., Sanche, S.E.: Propionibacterium acnes infections after cranial neurosurgery. Can J Neurol Sci 2006; 33: 292-295.

12. Korfali, L., Aksoy, K.: Preservation of craniotomy bone flaps under the scalp. Surg Neurol 1988; 30: 269-272.

13. Korinek, A.M.: Risk factors for neurosurgical site infections after craniotomy: a prospective multicenter study of 1944 patients. The French Study Group of Neurosurgical Infections, the SEHP, and the C-CLIN Paris-Nord. Service Epidemiologie Hygiene et Prevention. Neurosurgery 1997; 41:1073-1079.

14. Korinek, A.M., Golmard, J.L., Elcheik, A., et al.: Risk factors for neurosurgical site infections after craniotomy: a critical reappraisal of antibiotic prophylaxis on 4578 patients. Br J Neurosurg 2005; 19: 155-162.

15. Kourbeti, I.S., Anke, V., Koslow, M., Karabetsos, D., Holzman, R.S.: Rsik factors associated with postcraniotomy meningitis. Neurosurgery 2007; 60: 317-326.

16. Larsson, A., Engstrom, M., Uusijarvi, J., Kihlstrom,
L., Lind, F., Mathiesen, T.: Hyperbaric oxygen treatment of postoperative neurosurgical infections. Neurosurgery 2002; 50: 287-295.

17. Malis, L.I.: Prevention of neurosurgical infection by intraoperative antibiotics. Neurosurgery 1979; 5: 339-343.

18. Mindermann, T., Zimmerli, W., Gratzl,O.: Randomized placebo-controlled trial of single-dose antibiotic prophylaxis with fusidic acid in neurosurgery. Acta Neurochir (Wien) 1993; 121: 9-11.

19. Movassaghi, K., Ver Halen,J., Ganchi, P., Amin-Hanjani, S., Mesa, J., Yaremchuck, M.J.: Cranoplasty with subcutaneously preserved autologous bone graft. Plast Reconstr Surg 2006; 117: 202-206.

20. Osawa, M., Hara H., Ichinose, Y., Koyama, T., Kobayashi, S., Sugita, Y.: Cranioplasty with a frozen and autoclaved bone flap. Acta Neurochir (Wien) 1990; 102: 38-41.

21. Pons, V.G., Denlinger, S.L., Guglielmo, B.J., et al.: Ceftizoxime versus vancomycin and gentamicin in neurosurgical prophylaxis: a randomized, prospective, blinded clinical study. Neurosurgery 1993; 33: 416-422.

22. Rasmussen, S., Ohrstrom, J.K., Westergaard, L., Kosteljanetz, M.: Post-operative infections of osteoplastic compared with free bone flaps. Br J Neurosurg 1990; 4: 493-495.

23. Vanaclocha, V., Sáiz-Sapena, N., García-Casasola, C., De Alava, E.: Cranioplasty with autogenous autoclaved calvarial bone flan in the cases of tumoural invasion. Acta Neurochir (Wien) 1997; 139: 970-976.

Delgado-López, P.D.; Martín-Velasco, V.; Castilla-Díez, J.M.; Galacho-Harriero, A.M.; Rodríguez-Salazar, A.: Preservation of bone flap after craniotomy infection. Neurocitugía 2009; 20: 124-131.

Correspondencia postal; Pedro David Delgado López. Servicio de Neurocirugía. Hospital General Yagüe. Avda Cid 96, 09005 Burgos. 